\title{
Comparison Analysis Of Camels And Rgec In Assessing The Level Of Health Of Bank (Case Study In Pt Bank Rakyat Indonesia (Persero), Tbk Period 2017-2019)
}

\author{
Faramita Dwitama \\ Faculty of Computer Science and Information Technology, Gunadarma University, Indonesia \\ ${ }^{*}$ Corresponding author: \\ Email: faramita@staff.gunadarma.ac.id

\begin{abstract}
.
Bank soundness is the ability of a bank to carry out normal banking operations and is able to fulfill all of its obligations properly in ways that are in accordance with applicable regulations.This study aims to determine the comparison of the soundness level of the bank using the CAMELS method and the RGEC method at PT Bank Rakyat Indonesia (Persero), Tbk for the period 2017-2019. The type of data used is quantitative data and the data source used is secondary data.The results of this study indicate that (1) the soundness level of the bank at PT Bank Rakyat Indonesia (Persero), Tbk for the 2017-2019 period using the CAMELS method in the predicate "Very Healthy", (2) the soundness level of the bank at PT Bank Rakyat Indonesia (Persero), Tbk for the 2017-2019 period using the RGEC method in the predicate "Very Healthy", (3) comparison of the soundness of the bank at PT Bank Rakyat Indonesia (Persero), Tbk 2017-2019 period by using the CAMELS method and the RGEC method shows that there is no difference in the results of the analysis
\end{abstract} \\ because the two methods both obtain the predicate "Very Healthy".
}

Keywords: Bank Health, CAMELS, RGEC

\section{INTRODUCTION}

Bank is an institution that obtains permission to mobilize funds from the public in the form of deposits and distribute these funds to the public in the form of loans, so that the bank functions as an intermediary between savers and end users, households and companies (Khaerunnisa Said, 2012:1). With its role as a financial intermediary institution, the health of the financial institution concerned must be considered.To assess the health of a bank can be seen from various aspects. This assessment aims to determine whether the bank is in a healthy, moderately healthy, unhealthy or unhealthy condition. In conducting the bank health assessment, the government has determined through Bank Indonesia. Banks are required to make reports, both routine and periodic in nature, regarding all of their activities within a certain period. This report is studied and analyzed, so that it can be seen that its health condition will make it easier for the bank itself to improve its health.A healthy bank is a bank that can carry out its functions properly.

In other words, a healthy bank is a bank that can maintain and maintain public trust, can carry out the intermediation function, can help smooth payment traffic and can be used by the government in implementing various policies, especially monetary policy. In accordance with the development of the bank's business which is always dynamic and affects the level of risk faced, the methodology for assessing the soundness of the bank needs to be refined so that it can reflect the current and future conditions of the bank. These adjustments need to be made so that the assessment of the soundness of the bank can be more effectively used as a tool to evaluate bank performance. The previous bank health assessment used the CAMELS method. As time goes by and changes in the banking sector, the government creates new methods to assess the health of banks. The complete calculation guideline is regulated in Bank Indonesia Circular Letter (SE) No. 13/24/DPNP dated October 25, 2011 concerning Assessment of the Soundness of Commercial Banks, is an implementation guideline for Bank Indonesia Regulation No. 13/1/PBI/2011 which requires Commercial Banks to conduct a self-assessment of the Bank Soundness Level using a Risk-based Bank Rating (RBRR) approach, both individually but in a consolidated manner (www.bi.go.id, 2007) 


\section{LITERATURE REVIEW \\ Bank Health}

Bank health is the ability of a bank to carry out normal banking operations and be able to fulfill all its obligations properly in ways that are in accordance with applicable regulations (Sigit Triandaru and Totok Budisantoso, 2006:51).

The operational activities in question include:

1. Ability to raise funds.

2. Ability to manage funds.

3. Ability to channel funds to the community.

4. Ability to fulfill obligations to other parties.

5. Compliance with applicable regulations.

For banks, the final results of bank health research can be used as a means of determining future business strategies, while for Bank Indonesia the results of banking health research are used as a means of determining and implementing bank supervision strategies by Bank Indonesia.

\section{Analysis of Bank Soundness Level CAMELS Method}

According to the Circular Letter of Bank Indonesia No.6/23/DPNP/2004, the assessment of the soundness of a bank includes an assessment of the CAMELS factors consisting of:

\section{Capital (Capital)}

Capital Adequacy Ratio (CAR) is an analysis used to measure a bank's ability to meet its long-term obligations or the bank's ability to meet its obligations in the event of liquidation. The higher the percentage of the CAR ratio, it indicates that the bank's ability to absorb losses and manage its capital adequacy well.

\section{Asset Quality}

Earning Assets Quality (KAP), which is a ratio that measures the ability of the quality of Earning Assets owned by banks to cover Classified Earning Assets in the form of loans provided by banks.

\section{Management (Management)}

Net Profit Margin Ratio (NPM), which is a ratio to assess a bank's ability to generate net profit from its main operating activities. The greater the percentage of the NPM ratio, the better the bank's ability to generate net profits from its main operating activities.

\section{Profitability (Earnings)}

1) Return On Assets (ROA), which is a ratio that measures the ability of bank management to obtain overall profits from the total assets owned. The greater the percentage of the ROA ratio, the better the bank's management in obtaining overall profits from the total assets it owns.

2) Net Interest Margin (NIM), the ratio used to measure the management of productive assets so as to generate net interest income. The greater the percentage of the NIM ratio, the better the bank's ability to generate net interest income from the management of its productive assets.

\section{Liquidity}

The liquidity aspect with the Loan to Deposit Ratio (LDR) ratio can determine the bank's ability to pay all public funds by relying on distributed credit. The smaller the percentage of the LDR ratio obtained, it shows the better the bank is in managing the liquidity ratio.

\section{Sensitivity to Market Risk}

According to Ida Bagus and I.D.G Dharma (2017), an assessment of the sensitivity factor to market risk includes an assessment of the components, namely the ability of banks to cover potential losses as a result of fluctuations (adverse movement) of interest rates and exchange rates and adequacy of market risk management implementation.

\section{RGEC method}

According to Bank Indonesia Circular Letter No.13/24/DPNP/2011, the assessment of the soundness of a bank includes an assessment of the RGEC factors consisting of:

\section{Risk Profile (Risk Profile)}

The risk assessment is divided into 8 parts, namely:

1) Credit Risk 
It is a risk due to the failure of the debtor and/or other parties to fulfill their obligations to the bank. Generally, credit risk is present in all bank activities whose performance depends on the performance of the counterparty, issuer or borrower. The credit ratio is calculated using the Non Performing Loan (NPL) ratio.

\section{2) Market Risk}

This risk is the risk in the balance sheet and off balance sheet positions including derivative transactions, due to changes in market conditions, including the risk of changes in option prices. Market risk includes interest rate risk, exchange rate risk, equity risk, and commodity risk.

\section{3) Liquidity Risk}

It is a risk to determine the bank's ability to pay all public funds by relying on distributed credit. The liquidity ratio is calculated using the Loan to Deposit Ratio (LDR) ratio.

\section{4) Operational Risk}

Operational risk is a risk that occurs due to inadequate and/or malfunctioning internal processes, human error, system failure, and/or external events that affect bank operations. Operational risk It can be caused by human resources, processes, systems, and external events.

\section{5) Legal Risk}

This risk arises due to lawsuits and/or weaknesses in the juridical aspect. This risk can also arise due to the absence of the underlying laws and regulations or the weakness of the engagement, such as nonfulfillment of valid contractual requirements or inadequate collateral.

\section{6) Strategic Risk}

Is a risk that occurs due to the bank's inaccuracy in making decisions and/or implementing a strategic decision and failure to anticipate changes in the business environment. Sources of occurrence Strategic risk is caused by weaknesses in the strategy formulation process and inaccuracies in strategy formulation, inaccuracies in strategy implementation, and failure to anticipate changes in the business environment.

\section{7) Compliance Risk}

This risk arises as a result of the bank not complying with and/or not implementing the applicable laws and regulations. The source of compliance risk is due to lack of understanding or legal awareness of generally accepted business provisions and standards.

\section{8) Reputational Risk}

Is a risk that occurs due to a decrease in the level of stakeholder trust originating from a negative perception of the bank. The approach used in categorizing sources of reputational risk is indirect (below the line) and direct (above the line).

\section{RESEARCH METHOD}

The data analysis technique used in this study is to use quantitative descriptive analysis to explain in detail how the bank's soundness level at PT Bank Rakyat Indonesia (Persero), Tbk uses the CAMELS method and the RGEC method

\section{RESULTS AND DISCUSSIONS}

Result Camels Method
\begin{tabular}{|c|c|c|c|c|c|c|}
\hline Periode & CAR & KAP & NPM & ROA & NIM & LDR \\
\hline 2017 & $22,84 \%$ & $0,75 \%$ & $78,91 \%$ & $3,47 \%$ & $8,53 \%$ & $88,18 \%$ \\
& PK 1 & PK 1 & PK 3 & PK 1 & PK 1 & PK 3 \\
\hline 2018 & $21,35 \%$ & $0,81 \%$ & $77,66 \%$ & $3,44 \%$ & $7,95 \%$ & $89,58 \%$ \\
& PK 1 & PK 1 & PK 3 & PK 1 & PK 1 & PK 3 \\
\hline 2019 & $22,77 \%$ & $0,88 \%$ & $79,21 \%$ & $3,20 \%$ & $7,66 \%$ & $88,86 \%$ \\
& PK 1 & PK 1 & PK 3 & PK 1 & PK 1 & PK 3 \\
\hline
\end{tabular}

Based on the analysis conducted, Bank BRI's NPL ratio for the 2017-2019 period is categorized as "Very Healthy" (PK 1). Based on the analysis, the LDR ratio of Bank BRI for the period 2017-2019 is categorized as "Sufficiently Healthy" (PK 3). Based on the analysis conducted, BRI's GCG ratio for the 2017-2019 period is categorized as "Healthy" (PK 2). Based on the analysis conducted, BRI's ROA ratio for 
the 2017-2019 period is categorized as "Very Healthy" (PK 1). Based on the analysis, the NIM ratio of Bank BRI for the period 2017-2019 is categorized as "Very Healthy" (PK 1). Based on the analysis conducted, the CAR ratio of Bank BRI for the period 2017-2019 is categorized as "Very Healthy" (PK 1).

Result RGEC Method

\begin{tabular}{|c|c|c|c|c|c|c|}
\hline Periode & NPL & LDR & GCG & ROA & NIM & CAR \\
\hline 2017 & $1,10 \%$ & $88,18 \%$ & 2 & $3,47 \%$ & $8,53 \%$ & $22,84 \%$ \\
& PK 1 & PK 3 & PK 2 & PK 1 & PK 1 & PK 1 \\
\hline 2018 & $1,17 \%$ & $89,58 \%$ & 2 & $3,44 \%$ & $7,95 \%$ & $21,35 \%$ \\
& PK 1 & PK 3 & PK 2 & PK 1 & PK 1 & PK 1 \\
\hline 2019 & $1,31 \%$ & $88,86 \%$ & 2 & $3,20 \%$ & $7,66 \%$ & $22,77 \%$ \\
& PK 1 & PK 3 & PK 2 & PK 1 & PK 1 & PK 1 \\
\hline
\end{tabular}

Based on the analysis conducted, Bank BRI's NPL ratio for the 2017-2019 period is categorized as "Very Healthy" (PK 1). Based on the analysis, the LDR ratio of Bank BRI for the period 2017-2019 is categorized as "Sufficiently Healthy" (PK 3). Based on the analysis conducted, BRI's GCG ratio for the 2017-2019 period is categorized as "Healthy" (PK 2). Based on the analysis conducted, BRI's ROA ratio for the 2017-2019 period is categorized as "Very Healthy" (PK 1). Based on the analysis, the NIM ratio of Bank BRI for the period 2017-2019 is categorized as "Very Healthy" (PK 1). Based on the analysis conducted, the CAR ratio of Bank BRI for the period 2017-2019 is categorized as "Very Healthy" (PK 1).

\section{CONSLUSION}

Based on the results of the analysis of the soundness of banks at PT Bank Rakyat Indonesia (Persero), Tbk for the period 2017-2019, the following conclusions can be drawn:

1. Assessment of the soundness of the bank at PT Bank Rakyat Indonesia (Persero), Tbk using the CAMELS method shows that the predicate of the soundness of the bank is in accordance with the standards set by Bank Indonesia. In the 2017-2019 period, PT Bank Rakyat Indonesia (Persero), Tbk obtained the final score of the bank's soundness level of $86.67 \%$, resulting in the "Very Healthy" predicate.

2. Assessment of the soundness of the bank at PT Bank Rakyat Indonesia (Persero), Tbk using the RGEC method shows that the predicate of the soundness of the bank is in accordance with the standards set by Bank Indonesia. In the 2017-2019 period, PT Bank Rakyat Indonesia (Persero), Tbk obtained the final score of the bank's soundness level of $90 \%$, resulting in the title "Very Healthy".

3. The CAMELS and RGEC methods are two of several Bank Indonesia Regulations used to In 2017, the final score of Bank BRI's soundness level using the CAMELS method was $86.67 \%$ (Very Healthy), using the RGEC method of $90 \%$ (Very Healthy). In 2018, the final score of Bank BRI's soundness level using the CAMELS method was $86.67 \%$ (Very Healthy), using the RGEC method of $90 \%$ (Very Healthy). In 2019, the final score of Bank BRI's soundness level using the CAMELS method was 86.67\% (Very Healthy), using the RGEC method of $90 \%$ (Very Healthy). analyze the soundness of the bank. In the 2017-2019 period, there was no difference in the results of the analysis of the soundness of banks at PT Bank Rakyat Indonesia (Persero), Tbk because both methods both received the title "Very Healthy".

\section{SUGGESTIONS}

From the conclusions above, it can be used as a basis for providing advice, especially those related to bank health. The suggestions given by the author are as follows:

1. PT Bank Rakyat Indonesia (Persero), Tbk is expected to maintain and improve the health of the bank in the following years. A very healthy bank soundness level will increase the trust of the public, customers, employees, shareholders and other parties. As well as improving the company's performance based on quality and quantity so that the number of assets owned increases, the number of loans granted increases, and the profit earned for the following year continues to grow.

2. For further researchers, it is recommended to expand the scope of research on management assessment in CAMELS method and bank soundness assessment using 


\section{REFERENCES}

[1] Ida Bagus Brahmananda dan I.D.G Dharma Suputra, 2017. "Analisis Komparatif Tingkat Kesehatan Bank antara CAMELS dan RGEC PT. Bank BPD Bali Tahun 2012-2014”, E-Jurnal Akuntansi Universitas Udayana, Vol. 19, No. 1: 51-80.

[2] Jessica Chaniago. 2020. Analisis Tingkat Kesehatan PT. Bank DKI Menggunakan Perbandingan Metode CAMELS Tahun 2010 dan Metode RGEC Tahun 2018. Penelitian Ilmiah. Universitas Gunadarma.

[3] Marina Celya V. 2018. Perbandingan Perhitungan Tingkat Kesehatan Bank pada PT Bank Mandiri Tbk dengan Metode CAMELS dan Metode RGEC. Skripsi. Universitas Gadjah Mada.

[4] Ni Kadek Sri Widari, Ni Kadek Sinarwati, dan I Gusti Ayu Purnamawati, 2017. "Analisis Perbandingan dalam Menilai Tingkat Kesehatan Bank dengan menggunakan Metode CAMELS dan RGEC (Studi Kasus: PT Bank Rakyat Indonesia (Persero) Tbk tahun 2011- 2015)”, e-Journal S1 Ak Universitas Pendidikan Ganesha, Vol 7 , No. 1

[5] Rusdi Riduan Pulungan. 2019. Analisis Perbandingan Metode CAMELS dan RGEC dalam Menilai Tingkat Kesehatan Bank pada PT. Bank Panin Dubai Syariah Tbk. Skripsi. Institut Agama Islam Negeri Padangsidimpuan.

[6] Sigit Triandaru dan Totok Budisantoso. 2006. Bank dan Lembaga Keuangan indikator rasio keuangan lainnya pada pengukuran tingkat kesehatan bank. Lain. Edisi kedua. Jakarta: Salemba Empat.

[7] Sugiyono. 2010. Metode Penelitian Kuantitatif Kualitatif dan R\&D. Bandung: Alfabeta.

[8] Theresia Eka Putri. 2019. Analisis Perbandingan Metode CAMELS dan RGEC dalam Menilai Tingkat Kesehatan Bank pada PT. Bank Muamalat Indonesia Tbk Periode 2015-2017. Penelitian Ilmiah. Universitas Gunadarma. 